\title{
Cloud-oriented environment for flipped learning of the future IT specialists
}

\author{
Olena Glazunova ${ }^{1, *}$, Tetiana Voloshyna $^{2}$, Valentyna Korolchuk $^{2}$, and Oleksandra Parhomenko ${ }^{3}$ \\ ${ }^{1}$ National University of Life and Environmental Sciences of Ukraine, Faculty of Information Technology, Kyiv, 03041, Ukraine \\ ${ }^{2}$ National University of Life and Environmental Sciences of Ukraine, Department of Information and Distance Technologies, Kyiv, \\ 03041, Ukraine \\ ${ }^{3}$ National University of Life and Environmental Sciences of Ukraine, Department of Computer Science, Kyiv, 03041, Ukraine
}

\begin{abstract}
The article deals with the creation and use of the cloud-oriented environment for flipped learning in the process of training future IT specialists in higher education institutions. It describes the organization of the students' project work based on flipped learning using the services and resources of the cloud-oriented educational environment. It identified the following components of such an environment: resources of the university's training portal, mass open online courses, profession-oriented software applications and project management services. The present research offers the model of flipped learning for the implementation of the cross-disciplinary project for the formation of professional and personal competences of future IT specialists. It provides the results of an experimental study of the effectiveness of the proposed cloud-oriented environment application in the implementation of the cross-disciplinary project from the perspective of students and teachers by three criteria: functionality for professional activity, project management and flipped learning.
\end{abstract}

\section{Introduction}

Sustainable development depends on innovation and the introduction of ICT in various sectors of the economy and livelihoods. That is why providing inclusive and equitable quality education, promoting lifelong learning for all, is one of the global goals of sustainable development. The issue of training quality IT professionals is especially relevant in the context of achieving sustainable development goals, as modern innovation is based on the widespread use of IT. Higher education institutions are constantly confronted with the educational and technological challenges involved in preparing future IT specialists. Teachers are faced with the task of finding new approaches to solving the problem of improving the quality of the educational process, developing students' professional and personal skills. Moreover, employers' expectations of professional qualification requirements must be met. In addition to professional competencies, teamwork, problem-solving and communication skills, so-called soft skills, should be addressed in the future IT specialists.

We are looking at flipped learning as a way of creating a learning ecosystem, we realise how effective it is. Flipped classrooms connect people and provide them with a variety of content and technology. This increases the engagement of the learners as there is activity-based, practical learning in classroom time. Flipped learning also boosts healthy interaction between members, in a mutually beneficial manner, which is the essential function of an ecosystem. Blended learning, interaction between members and informal learning are other characteristics of a flipped classroom that take you closer to developing a learning ecosystem.

Case studies are emerging, in ever greater numbers, which document measurable improvements in student and teacher motivation, increased attendance in class, and better grades, as a result of using the flipped approach [1, $2,3]$.

Innovative approaches in higher education are shifting away from teacher centered instruction to studentcentered learning [4].

Technological challenges and the need to develop personal performance and self-education competences of future IT specialists pose the challenge of designing an effective educational environment. The purpose of this article is to design a cloud-oriented environment for flipped learning in the process of training the future IT specialists, as well as to study the performance indicators of such an environment.

\section{Theoretical background}

There are two common characteristics which encapsulate a flipped classroom: (a) an easily adaptable learning environment that facilitates active learning and allows students to develop different skills and competencies [5, $6,7,8]$; (b) a student-centred learning culture $[2,9]$ and others.

* Corresponding author: o-glazunova@nubip.edu.ua 
According to the Flipped Learning Network the flipped classroom approach has four pillars. In order for teachers to achieve this approach, they have to take these four elements into consideration:

- Flipped learning requires flexible environments.

- Flipped learning requires a shift in learning culture.

- Flipped learning requires intentional content.

- Flipped learning requires professional educators.

The concept of flipped learning is to provide to student's lectures in a video format and other supportive materials to review as their homework, get the maximum of it, and then, use the next class time for in-class activities and problem-solving exercises. The flipped classroom serves as a platform to achieve a collaborative and organic learning environment. To meet the challenges and complexities of the 21 st-century workplace environment, there has been a shift and adoption of an organic learning environment in the business community. Similarly, universities and accreditation bodies in business schools are moving towards developing competency-based curricula where learners foster lifelong learning skills through a process of self-directed learning [10].

Flipped learning approaches have students use technology to access the lecture and other instructional resources outside the classroom in order to engage them in active learning during in-class time [11].

O. Kuzminska, N. Morze, E. Smyrnova-Trybulska describes scenarios and collaboration tools for students' practical activity, provides examples of learning objects representing resources for independent study and research, and criteria for assessing the effectiveness of the proposed model of flipped learning [6].

The active learning techniques integrate the student centered learning methods such as cooperative learning, problem-based learning, project based learning and peer assisted learning. These learning approaches mean that students work in groups in order to develop and reach their learning goals [4].

One of the aims of the flipped learning technology is the transition of the educational process organization from passive student learning to the active one, in which future specialists participate in collaborative work, carry out team projects, discuss and solve practical problems in the classroom, applying the theoretical knowledge they have acquired prior to the classroom lessons. By providing students with basic theoretical knowledge prior to the class, the teacher becomes a facilitator, thus enabling students to deepen their knowledge and practical skills during the class and independently manage their own educational process.

The scheme of the educational process organization under the flipped learning technology of future specialists in information technologies is presented in Fig. 1.

Prior to the classes, students need to acquire basic theoretical knowledge in each academic subject using the resources of the e-learning course (ELC), further deepen the acquired knowledge independently by studying the various MOOCs recommended by teachers. During the classes, students plan joint activities, work on the project as a team, performing practice-based tasks. In the classroom, students consult the teacher on the problematic issues. After classes, the student teams performed tasks assigned to each participant within the project and addressed controversial issues if they arouse among the team members regarding the project tasks.

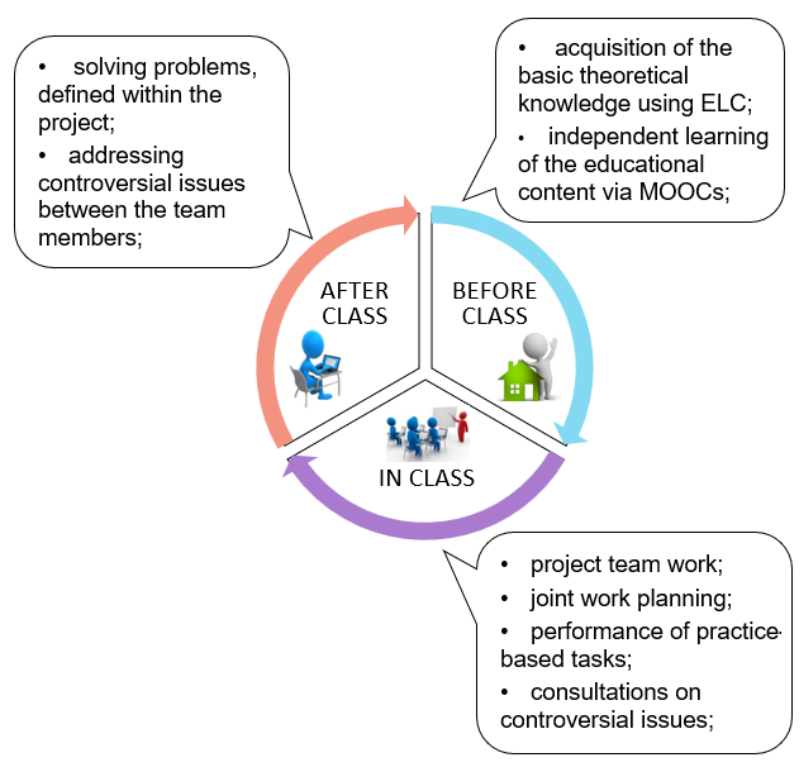

Fig. 1. The scheme of the educational process organization under the flipped learning technology.

The use of modern information technologies further enriches the flipped learning process and foster the skills needed by future IT specialists. At the World Economic Forum in 2019, it was determined that it is important to pay attention to the ways and forms of the educational process organization, out of which they single out the study of information technologies with an emphasis on teamwork and creativity, learning through games that develop critical thinking, support of students' initiative outside the educational programs.

A cloud-based environment for organizing the learning process through the technology of flipped learning should provide e-support for the activities of students and teachers at the stages "before class", "in class", "after class". The essence of the notion and the possibility of using a learning environment in their studies are considered by the following scientists: O. Saad, M. Rana [12], A. Salam, N. Sardar [13], M. Shyshkina [14, 15], Y. Nosenko, M. Shyshkina, V. Oleksiuk [16], M. Popel [17] et al.

O. Spirin, V. Oleksiuk, N. Balyk, S. Lytvynova, and S. Sydorenko describe a cloud environment for the study of the "Computer Networks" academic discipline in their article [18], which was deployed at the Faculty of Physics and Mathematics of Ternopil Volodymyr Hnatyuk National Pedagogical University and investigate the effectiveness of blended learning in such an environment.

Supported by the information and communication technologies, teachers have many options for improving the effectiveness of teaching, in particular the organization of teamwork projects in the process of training future IT specialists.

The cloud-oriented environment was designed at the National University of Life and Environmental Sciences (NULES) of Ukraine for training the future IT specialists 
under the flipped learning technology (Fig. 2). Selection criteria for cloud services and resources that will be appropriate in the process of training future IT professionals are analysed in articles [19]. The university's cloud-oriented environment provides students, who major in IT with a variety of types of resources and services that make it possible to use:

- prior to classes within the framework of independent work with e-resources: e-learning courses (ELC) in accordance with the curriculum for training specialists using the LMS Moodle platform; Khan Academy; online courses from Microsoft and Cisco leading technology companies, respectively, Microsoft Imagine Academy, Cisco Networking Academy; Massive Open Online courses (MOOC), such as Coursera, Udemy, Prometheus, edX, Khan Academy and others;

- in the classroom: professionally-oriented software and cloud services, namely: Microsoft Office 365; Visual Studio; draw.io; services for collective IT development (GitHub, Bitbucked, DeployBot, Phabricator, BeanStalk); Miro;

- for the cooperation outside the university, services to manage collective projects such as: Microsoft Teams, Jira, Trello, Asana, YouTrack.

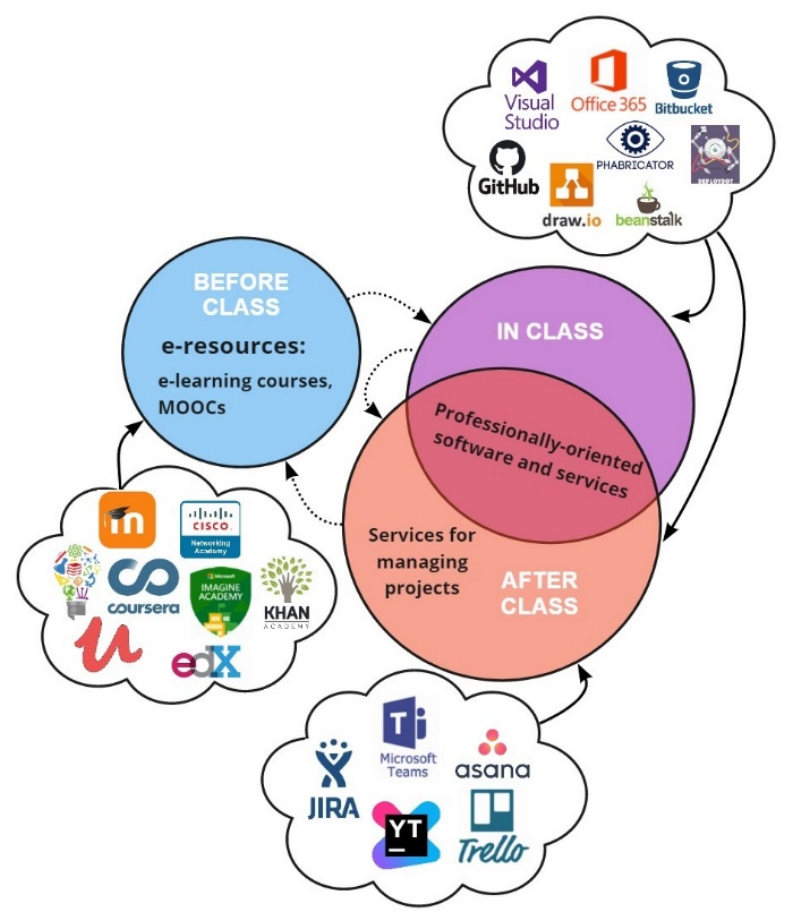

Fig. 2. Components of the cloud-oriented environment for flipped learning.

The design of a cloud-oriented environment for the implementation of the cross-disciplinary project enables teachers to choose the means available to complete the project's tasks, integrate the necessary services and resources into the created environment, and provide communication between the educators, who teach the project disciplines and the teams of students; students have the opportunity to effectively plan project implementation steps, distribute tasks among team members and monitor their implementation, organize teamwork to create the end product of the project.

\section{Presentation of research}

The cross-disciplinary project provided for a combination of the tasks of the three disciplines, namely: System Analysis, Web Technologies and Web Design, Economics and Business. This project was implemented under flipped learning technology using the designed cloud-based university environment. To ensure the work of students on the implementation of this project at the stage of organization, a schedule for the implementation of the project was developed and a project day was allocated, during which the students performed the task.

The students were offered to implement the crossdisciplinary project on the topic of "Web-oriented system for the IT industry", with the purpose of carrying out systematic analysis, developing a web-oriented system and evaluating the investment attractiveness of the developed system. The content of the project was to develop a project for starting their own IT-business, namely: conducting an analysis of the IT services market; carrying out structural, functional and object-oriented analysis of the domain; designing the database and system functionality; developing a web-based system for the IT company; creating a business plan for the company and accordingly calculating the payback of the project as well as strategizing the company's development.

We distinguish the following 8 stages of such a collaborative project implementation under the flipped learning technology: setting a task and processing theoretical material (1); structuring the task and subdividing it into specific tasks (2); role distribution, definition of terms and responsibilities (3); performance of basic tasks (4); joint work of the task team (5); assessment of the quality of the task (6); drawing up a report on the work performed (7); presentation of results (8).

The teamwork was subdivided into 3 parts, according to the tasks of each academic discipline that were part of the cross-disciplinary project. In the course of completing the tasks in the "System Analysis" academic discipline, the students had to conduct an analysis of the IT services market, to choose the profile of the future company, to develop the functionality of the future business, to carry out structural-and-functional and object-oriented analysis, to design information support and to describe the specification of management processes. In the course of "Web Design and Web Technologies" academic disciplines, the students developed the website of the future company and integrated it into the information management system of the company. The tasks in the "Economics and Business" academic discipline required students to analyze the necessary tools to start their own business, to develop a business plan for the future company, to formulate a strategy for its further development, to calculate the basic income and expenditure, as well as to evaluate its economic efficiency and investment attractiveness.

Prior to the commencement of training (before class): instructions were developed for each task of the project beforehand, and necessary training materials were placed in electronic training courses (ELCs) for each academic discipline. The teaching materials at ELCs were designed 
according to the students' learning styles. Often the same material was offered in different formats according to the research provided in [20]. Thus, the students studied basic theoretical materials in the ELC of the corresponding academic disciplines, got acquainted with the project objectives, registered and selected MOOCs for the independent study of the required material in accordance with their learning style. An in-depth study of the theoretical material, required for students to complete the assignments, took place in lectures alternately in each academic discipline as per schedule. The students studied the selected professionally oriented software and project management services offered by the teachers for each stage of the cross-disciplinary project.

In class: all the students were required to participate weekly in interactive lectures and laboratory work. During such classes, students were asked to develop a project based on the tasks of three identified academic disciplines of the cross-disciplinary project. The first session involved getting acquainted with the subject and tasks of the project in detail in each academic discipline. The students were divided into teams of 4 people, then within the team they were assigned roles and areas of responsibility of each team member; further the team members defined the terms of implementation and appointed those responsible for each project task. The task of the students was to understand the problem, to evaluate the complexity of the works, to find options for their solution, to divide the received tasks into separate tasks, to apply the theoretical and practical knowledge acquired before the beginning of classes to solve the project's tasks. In class the students were advised by the teacher on the progress of the course; they acquired basic skills in performing specific tasks via professionally oriented software and services of the university cloud-oriented environment.

After class: team members jointly performed project tasks in each academic discipline, collaborated using project management and IT-team services. In the course of the project, the students evaluated the tasks completed personally as well as those completed by other team members. If necessary, they refined the tasks to the appropriate professional level, created reports in the form of a presentation, which reflected the results of the team at all stages of the project. In the end, each team presented the results of their project, and teachers and participants of other teams evaluated the readiness for the implementation.

Fig. 3 shows a diagram of one of the cycles of fulfilling the tasks of a cross-disciplinary project under the flipped learning technology using the cloud-oriented university environment.

Table 1 defines in more detail the types of activities in the process of the implementation of each stage of the project, during which the students develop professional, integrated, self-educational competences and soft skills, for each of the above stages of the cross-disciplinary project using a cloud-oriented environment.

Thus, the implementation of such cross-disciplinary project tasks involved activities at certain stages, which resulted in the development of professional, integrated, self-educational competences, as well as communication, interpersonal, leadership, teamwork and time management skills, the so-called "soft skills".

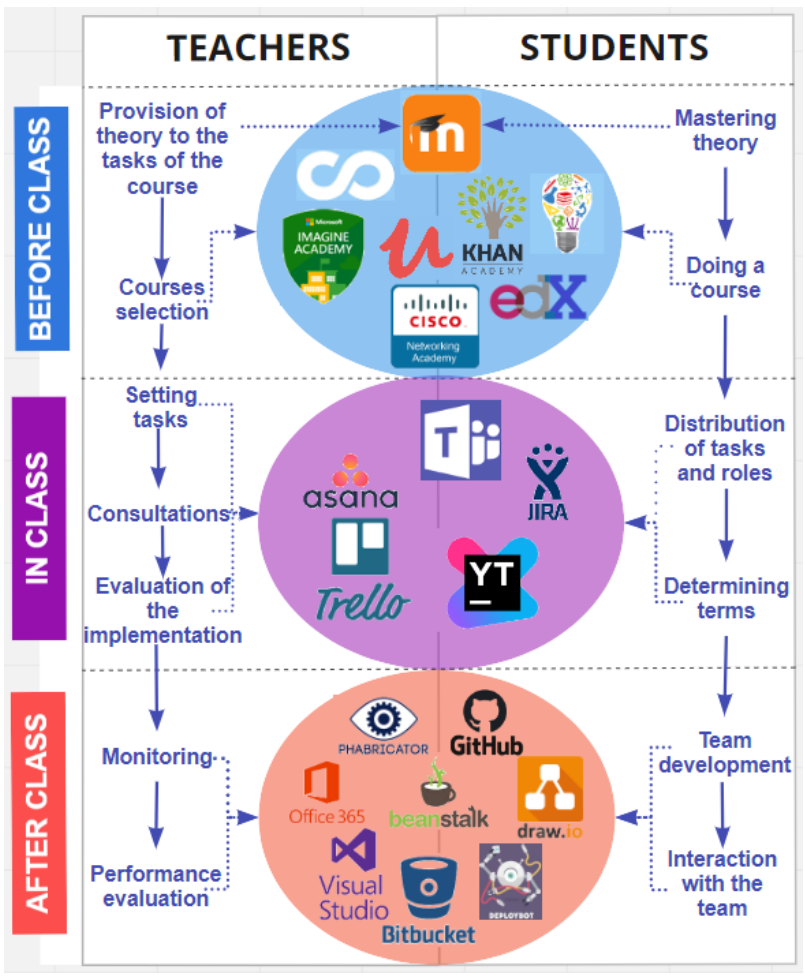

Fig. 3. The diagram of one cycle of the cross-disciplinary project under the flipped learning technology using the cloudoriented university environment.

Table 1. Organization of the cross-disciplinary project under the flipped learning technology using the cloud-oriented environment.

\begin{tabular}{|c|c|c|c|}
\hline $\begin{array}{l}\text { Con- } \\
\text { tents of } \\
\text { the sta- } \\
\text { ge }\end{array}$ & Activity & Tools & Competence \\
\hline \multicolumn{4}{|c|}{ Before class } \\
\hline $\begin{array}{l}\text { Setting } \\
\text { tasks and } \\
\text { maste- } \\
\text { ring of } \\
\text { the theo- } \\
\text { retical } \\
\text { material }\end{array}$ & $\begin{array}{l}\text { getting acquainted } \\
\text { with the aim and } \\
\text { tasks of the project; } \\
\text { studying the theo- } \\
\text { retical material in } \\
\text { ELC; } \\
\text { registration and se- } \\
\text { lection of MOOC; } \\
\text { doing online cour- } \\
\text { ses }\end{array}$ & $\begin{array}{l}\text { LMS Mo- } \\
\text { odle; } \\
\text { Cisco Aca- } \\
\text { demy; } \\
\text { Promethe- } \\
\text { us; } \\
\text { Coursera; } \\
\text { Microsoft } \\
\text { Imagine } \\
\text { Academy; } \\
\text { Udemy; } \\
\text { Khan Aca- } \\
\text { demy }\end{array}$ & $\begin{array}{l}\text { self-educational; } \\
\text { professional; } \\
\text { ability to search, } \\
\text { process and analy- } \\
\text { ze information } \\
\text { from various sour- } \\
\text { ces }\end{array}$ \\
\hline \multicolumn{4}{|c|}{ In class } \\
\hline $\begin{array}{l}\text { Structu- } \\
\text { ring the } \\
\text { material } \\
\text { and divi- } \\
\text { ding it } \\
\text { into spe- } \\
\text { cific } \\
\text { tasks }\end{array}$ & $\begin{array}{l}\text { evaluation of the } \\
\text { task complexity; } \\
\text { search for solutions } \\
\text { to the problem; } \\
\text { division of the task } \\
\text { into separate tasks }\end{array}$ & $\begin{array}{l}\text { Microsoft } \\
\text { Teams; } \\
\text { Jira; } \\
\text { Trello; } \\
\text { Asana; } \\
\text { YouTrack }\end{array}$ & $\begin{array}{l}\text { ability to work in a } \\
\text { team; } \\
\text { knowledge and un- } \\
\text { derstanding of the } \\
\text { subject area; } \\
\text { ability to make de- } \\
\text { cisions }\end{array}$ \\
\hline
\end{tabular}




\begin{tabular}{|c|c|c|c|}
\hline $\begin{array}{l}\text { Con- } \\
\text { tents of } \\
\text { the sta- } \\
\text { ge }\end{array}$ & Activity & Tools & Competence \\
\hline $\begin{array}{l}\text { Alloca- } \\
\text { ting ro- } \\
\text { les, ap- } \\
\text { pointing } \\
\text { people in } \\
\text { charge, } \\
\text { setting } \\
\text { the date }\end{array}$ & $\begin{array}{l}\text { allocation of roles } \\
\text { and areas of res- } \\
\text { ponsibility of each } \\
\text { team member; } \\
\text { appointment of } \\
\text { those responsible } \\
\text { for each task; } \\
\text { determining the ti- } \\
\text { ming of each task } \\
\end{array}$ & $\begin{array}{l}\text { Microsoft } \\
\text { Teams; } \\
\text { Jira; } \\
\text { Trello; } \\
\text { Asana; } \\
\text { YouTrack }\end{array}$ & $\begin{array}{l}\text { ability to work in a } \\
\text { team; ability to } \\
\text { make decisions }\end{array}$ \\
\hline $\begin{array}{l}\text { Perfor- } \\
\text { ming ba- } \\
\text { sic tasks }\end{array}$ & $\begin{array}{l}\text { solving practical } \\
\text { tasks according to } \\
\text { the aim of the task } \\
\text { performance; } \\
\text { consultation with } \\
\text { the teacher on } \\
\text { problematic issues }\end{array}$ & $\begin{array}{l}\text { GitHub; } \\
\text { Bitbucked; } \\
\text { DeployBot; } \\
\text { Phabricator; } \\
\text { BeanStalk; } \\
\text { professio- } \\
\text { nally-orien- } \\
\text { ted software } \\
\text { and services }\end{array}$ & $\begin{array}{l}\text { professional; } \\
\text { integral; } \\
\text { the ability to apply } \\
\text { knowledge in } \\
\text { practical situations }\end{array}$ \\
\hline \multicolumn{4}{|c|}{ After class } \\
\hline $\begin{array}{l}\text { Team } \\
\text { work on } \\
\text { task } \\
\text { comple- } \\
\text { tion }\end{array}$ & $\begin{array}{l}\text { step-by-step imple- } \\
\text { mentation of pro- } \\
\text { ject tasks in each } \\
\text { academic dis- } \\
\text { cipline (domain } \\
\text { analysis, site deve- } \\
\text { lopment, project } \\
\text { cost-performance } \\
\text { calculation) }\end{array}$ & $\begin{array}{l}\text { GitHub; } \\
\text { Bitbucked; } \\
\text { DeployBot; } \\
\text { Phabricator; } \\
\text { BeanStalk; } \\
\text { professio- } \\
\text { nally-orien- } \\
\text { ted software } \\
\text { and services }\end{array}$ & $\begin{array}{l}\text { professional; } \\
\text { integral; } \\
\text { the ability to apply } \\
\text { knowledge in } \\
\text { practical situations }\end{array}$ \\
\hline $\begin{array}{l}\text { Evaluati- } \\
\text { on of the } \\
\text { quality } \\
\text { of the } \\
\text { task per- } \\
\text { formed }\end{array}$ & $\begin{array}{l}\text { evaluation of inde- } \\
\text { pendently com- } \\
\text { pleted tasks; } \\
\text { evaluation of tasks } \\
\text { performed by other } \\
\text { team members; } \\
\text { refinement of tasks }\end{array}$ & $\begin{array}{l}\text { GitHub; } \\
\text { Bitbucked; } \\
\text { DeployBot; } \\
\text { Phabricator; } \\
\text { BeanStalk; } \\
\text { professio- } \\
\text { nally-orien- } \\
\text { ted software } \\
\text { and services }\end{array}$ & $\begin{array}{l}\text { ability to be criti- } \\
\text { cal and self-criti- } \\
\text { cal; } \\
\text { the ability to eva- } \\
\text { luate and ensure } \\
\text { the quality of work } \\
\text { performed }\end{array}$ \\
\hline $\begin{array}{l}\text { Report } \\
\text { genera- } \\
\text { ting on } \\
\text { the work } \\
\text { perfor- } \\
\text { med }\end{array}$ & $\begin{array}{l}\text { generating a team } \\
\text { work report on the } \\
\text { project }\end{array}$ & $\begin{array}{l}\text { PowerPoint } \\
\text { Online; } \\
\text { Sway }\end{array}$ & $\begin{array}{l}\text { the ability to visu- } \\
\text { alize, formulate, } \\
\text { solve problematic } \\
\text { situations, making } \\
\text { the right decisions, } \\
\text { taking into account } \\
\text { available informa- } \\
\text { tion }\end{array}$ \\
\hline $\begin{array}{l}\text { Presenta- } \\
\text { tion of } \\
\text { results }\end{array}$ & $\begin{array}{l}\text { report placement; } \\
\text { evaluation }\end{array}$ & Miro & $\begin{array}{l}\text { the ability to } \\
\text { present the project } \\
\text { to investors or } \\
\text { your own team }\end{array}$ \\
\hline
\end{tabular}

\section{Results of research}

The timeframe of the study is 3 years. The pedagogical experiment involved students of the 3 rd year of Computer Science specialty at the Faculty of Information Technologies of NULES of Ukraine. We conducted an expert evaluation using a survey among students of NULES of Ukraine.

To understand the attitude of students to the cloudoriented environment of the university, we have defined 3 criteria for evaluating them from the standpoint of functionality of the cloud-oriented environment:
- to perform professional tasks;

- to implement the flipped learning technology;

- to manage project implementation.

Indicators under the first criterion include: accessibility (ability to work from any device); reliability (high-quality functioning of the cloud-oriented environment); flexibility (designed and used in line with learning objectives); expediency (need for use to solve problems); convenience (clarity and ease of use); support for processes (communication, collaboration, cooperation, planning and control); teamwork (the ability to organize teamwork, create team projects); integrity (ensuring a continuous educational process); integration with other cloud services; support of various programming technologies; the ability to access open code software.

Indicators under the second criterion are the following: availability of training resources in a cloudoriented environment; completeness of educational material for students to acquire theoretical knowledge independently; completeness of training material necessary for practical tasks; convenience for independent preparation for the class; convenience of interaction of team members in practical activity; convenience for selfcontrol; convenience for checking the level of acquired knowledge.

Indicators under the third criterion are the following: ease of team work organization; convenience in planning the work on a collaborative project; ease of roles and areas of responsibility allocation for each team member; the convenience of controlling the timing of each task; convenience of communication among the team members; ease of interaction of team members during team development; ease of checking completed tasks; ease of managing software versions.

In order to determine the effectiveness of the cloudoriented environment under the above-mentioned categories and evaluation indicators, 34 students and 8 teachers were interviewed after conducting a crossdisciplinary project based on flipped learning technology using the cloud-oriented environment. A questionnaire was developed in which students and teachers were asked to rate the importance of each of the previously identified environmental indicators by three categories separately (Table 2-4).

Experts evaluated the degree of significance of parameters by assigning them a ranking number. The highest rated indicator was assigned a rank of 1 .

To evaluate the consistency of experts' opinions, we used the concordance coefficient, which was calculated by the formula:

$$
\begin{gathered}
W=\frac{12 S}{m^{2}\left(n^{3}-n\right)} \\
S=\left(\sum x_{i j}-\frac{\sum \sum x_{i j}}{n}\right)^{2}
\end{gathered}
$$

where $n-$ is the number of factors, $m-$ is the number of experts.

The weights of the considered parameters were calculated on the basis of the sums obtained. 
Table 2. Evaluation of the results for determining the performance of a cloud-oriented environment.

\begin{tabular}{|c|c|c|c|c|c|c|}
\hline \multirow[b]{2}{*}{ Indicators } & \multicolumn{3}{|c|}{$\begin{array}{l}\text { Teaching } \\
\text { staff }\end{array}$} & \multicolumn{3}{|c|}{ Students } \\
\hline & 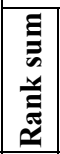 & $\infty$ & $\frac{E}{200}$ & 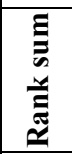 & $\infty$ & $\frac{E}{300}$ \\
\hline $\begin{array}{l}\text { accessibility (ability to work } \\
\text { from any device) }\end{array}$ & 80 & 1024 & 0.02 & 164 & 1600 & 0.11 \\
\hline $\begin{array}{l}\text { reliability (high-quality } \\
\text { functioning of the cloud- } \\
\text { oriented environment) }\end{array}$ & 52 & 16 & 0.08 & 297 & 8649 & 0.04 \\
\hline $\begin{array}{l}\text { flexibility (designed and } \\
\text { used in line with learning } \\
\text { objectives) }\end{array}$ & 10 & 1444 & 0.18 & 237 & 1089 & 0.07 \\
\hline $\begin{array}{l}\text { expediency (need for use to } \\
\text { solve problems) }\end{array}$ & 54 & 36 & 0.08 & 311 & 11449 & 0.03 \\
\hline $\begin{array}{l}\text { convenience (clarity and } \\
\text { ease of use) }\end{array}$ & 52 & 16 & 0.08 & 264 & 3600 & 0.06 \\
\hline $\begin{array}{l}\text { support for processes } \\
\text { (communication, } \\
\text { collaboration, cooperation, } \\
\text { planning and control) }\end{array}$ & 20 & 784 & 0.15 & 47 & 24649 & 0.17 \\
\hline $\begin{array}{l}\text { teamwork (the ability to } \\
\text { organize teamwork, create } \\
\text { team projects) }\end{array}$ & 34 & 196 & 0.12 & 204 & 0 & 0.09 \\
\hline $\begin{array}{l}\text { integrity (ensuring a } \\
\text { continuous educational } \\
\text { process) }\end{array}$ & 41 & 49 & 0.11 & 329 & 15625 & 0.02 \\
\hline $\begin{array}{l}\text { integration with other cloud } \\
\text { services }\end{array}$ & 36 & 144 & 0.12 & 137 & 4489 & 0.13 \\
\hline $\begin{array}{l}\text { support of various } \\
\text { programming technologies }\end{array}$ & 67 & 361 & 0.05 & 73 & 17161 & 0.16 \\
\hline $\begin{array}{l}\text { the ability to access open } \\
\text { code software }\end{array}$ & 82 & 1156 & 0.01 & 181 & 529 & 0.1 \\
\hline Total & 528 & 5226 & 1 & 2244 & 88840 & 1 \\
\hline Concordance coefficient & & 0.742 & & & 0.693 & \\
\hline Calculated $\chi^{2}$ & & 59.36 & & & 235.62 & \\
\hline Table $\chi^{2}(k=10, \alpha=0,05)$ & & 18.309 & & & 18.309 & \\
\hline
\end{tabular}

When evaluating the performance of a cloud-oriented environment, the teaching staff found out that flexibility, support for the process, teamwork, and integration with other cloud services were the most important indicators. The concordance coefficient was 0.742 , which indicates a high level of agreement of experts' opinions.

The significance of the concordance coefficient was determined by the Pearson correlation criterion: $\chi^{2}=m(n-1) W$. Comparing the calculations of $\chi^{2}$ (59.36) with table values (18.309) when number of degrees of freedom is $K=n-1=11-1=10$ with the given significance value of $\alpha=0.05$, we may conclude that $W=0.742$ - is not a random value, and therefore the obtained values are statistically significant.

In evaluating the performance of a cloud-oriented environment, students identified the following most important indicators: support for the process, support of various programming technologies, integration with other cloud services, and accessibility. The concordance coefficient was 0.693 , which indicates the average degree of agreement of experts' opinions.
Table 3. Evaluation of the results of determining the effectiveness of the cloud-oriented environment for the project activity.

\begin{tabular}{|c|c|c|c|c|c|c|}
\hline \multirow[b]{2}{*}{ Indicators } & \multicolumn{3}{|c|}{$\begin{array}{l}\text { Teaching } \\
\text { staff }\end{array}$} & \multicolumn{3}{|c|}{ Students } \\
\hline & 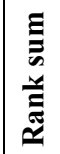 & $\boldsymbol{O}$ & ह⿸\zh14𠃋 & 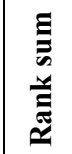 & $\infty$ & $\frac{5}{200}$ \\
\hline \begin{tabular}{|l|} 
ease of teamwork \\
organization
\end{tabular} & 11 & 625 & 0.24 & 56 & 9409 & 0.23 \\
\hline $\begin{array}{l}\text { convenience in planning the } \\
\text { work on a collaborative } \\
\text { project }\end{array}$ & 22 & 196 & 0.19 & 162 & 81 & 0.12 \\
\hline $\begin{array}{l}\text { ease of roles and areas of } \\
\text { responsibility allocation for } \\
\text { each team member }\end{array}$ & 51 & 225 & 0.06 & 243 & 8100 & 0.03 \\
\hline $\begin{array}{l}\text { convenience of controlling } \\
\text { the timing of each task }\end{array}$ & 54 & 324 & 0.04 & 185 & 1024 & 0.09 \\
\hline $\begin{array}{l}\text { convenience of } \\
\text { communication among the } \\
\text { team members }\end{array}$ & 61 & 625 & 0.01 & 156 & 9 & 0.12 \\
\hline $\begin{array}{l}\text { ease of interaction of team } \\
\text { members during team } \\
\text { development }\end{array}$ & 15 & 441 & 0.22 & 68 & 7225 & 0.21 \\
\hline \begin{tabular}{|l} 
ease of checking completed \\
tasks
\end{tabular} & 33 & 9 & 0.14 & 256 & 10609 & 0.02 \\
\hline $\begin{array}{l}\text { ease of managing software } \\
\text { (program code) versions }\end{array}$ & 41 & 25 & 0.06 & 98 & 3025 & 0.18 \\
\hline Total & 288 & 2470 & 1 & 1224 & 39482 & 1 \\
\hline Concordance coefficient & & 0.918 & & & 0.813 & \\
\hline Calculated $\chi^{2}$ & & 51.48 & & & 193.49 & \\
\hline Table $\chi^{2}(k=7, \alpha=0.05)$ & & 14.06 & & & 14.068 & \\
\hline
\end{tabular}

Table 4. Evaluation of the results of determining the effectiveness of a cloud-oriented environment for flipped learning.

\begin{tabular}{|c|c|c|c|c|c|c|}
\hline \multirow[b]{2}{*}{ Indicators } & \multicolumn{3}{|c|}{$\begin{array}{l}\text { Teaching } \\
\text { staff }\end{array}$} & \multicolumn{3}{|c|}{ Students } \\
\hline & 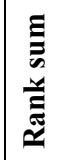 & $\boldsymbol{n}$ & $\sum^{\frac{1}{200}}$ & 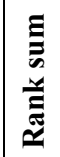 & $\infty$ & $\frac{1}{500}$ \\
\hline $\begin{array}{l}\text { availability of training } \\
\text { resources in a cloud-oriented } \\
\text { environment }\end{array}$ & 37 & 25 & 0.11 & 99 & 1369 & 0.19 \\
\hline $\begin{array}{l}\text { completeness of educational } \\
\text { material for students to } \\
\text { acquire theoretical knowledge } \\
\text { independently }\end{array}$ & 17 & 225 & 0.23 & 207 & 5041 & 0.04 \\
\hline $\begin{array}{l}\text { completeness of training } \\
\text { material necessary for } \\
\text { practical tasks }\end{array}$ & 28 & 16 & 0.17 & 57 & 6241 & 0.25 \\
\hline $\begin{array}{l}\text { convenience for independent } \\
\text { preparation for the class }\end{array}$ & 46 & 196 & 0.06 & 145 & 81 & 0.13 \\
\hline $\begin{array}{l}\text { convenience of interaction of } \\
\text { team members in practical } \\
\text { activity }\end{array}$ & 33 & 1 & 0.14 & 167 & 961 & 0.10 \\
\hline possibility of self-control & 52 & 400 & 0.02 & 66 & \begin{tabular}{|l|}
4900 \\
\end{tabular} & 0.24 \\
\hline convenience for checking & 11 & 441 & 0.27 & 211 & 5625 & 0.04 \\
\hline Total & 224 & 1304 & 1 & 952 & 24218 & 1 \\
\hline Concordance coefficient & & 0.728 & & & 0.748 & \\
\hline Calculated $\chi^{2}$ & & 34.94 & & & 152.592 & \\
\hline Table $\chi^{2}(k=6, \alpha=0,05)$ & & 12.59 & & & 12.593 & \\
\hline
\end{tabular}


When evaluating the effectiveness of a cloud-oriented environment for the project activity, teachers singled out the following indicators as the most important ones: convenience of organizing teamwork, the ease of interaction of team members in team development, and the ease of planning for a team project. According to the students, the most important indicators are the ease of teamwork organization, the ease of interaction of team members during team development and the ease of managing software (program code) versions.

Evaluating the effectiveness of the cloud-oriented environment for flipped learning, the teachers noted that the convenience of checking the level of acquired knowledge, completeness of educational material for students' independent mastering of theoretical knowledge and completeness of educational material needed to perform practical tasks were the most important indicators.

\section{Conclusions}

In the course of the study, which lasted for 3 years, a cloud-oriented environment was designed to perform cross-disciplinary projects under the flipped learning technology in the process of training future IT specialists. The designed environment is a major component of the ecosystem of flipped learning. The theoretical and practical importance for achieving the goal of sustainable development for the quality education of future IT professionals is to justify the quality criteria of such an environment. The main functional components of such an environment are cloud services for professional activity, for the implementation of the technology of flipped learning and project management. The cloud services and tools used and the activities of the student and the teacher are identified at each stage of the cross-disciplinary project implementation. One of the most important results obtained during the study was the identification of performance indicators for the developed cloud-based environment model, which cover the functionality of the environment by 3 criteria, namely: for the professional activity, for the implementation of the flipped learning technology and for the project management. The analysis of the results of the survey of students and teachers on three criteria makes it possible to draw conclusions about the consistency of their opinions. However, some indicators are considered more important as seen by the students than by teachers. They are: the availability of learning resources in a cloud environment, the completeness of training material for practical tasks, support for various programming technologies, ease of managing software (program code) versions. At the same time, teachers highlight the following indicators with greater weight as opposed to students: the convenience of checking the stages of tasks completion, the ease of checking completed tasks, the flexibility of the environment, the completeness of material for the students' independent work. Equally important to both students and the teachers are the following indicators: support for project implementation processes, integration with other resources and services, ease of teamwork, ease of planning and interaction among project participants. Thus, the most significant indicators of e-environment performance for flipped learning in the team project implementation are identified. In the future, it is advisable to investigate the impact of the use of the developed environment on the formation of professional and personal competences of the students of IT profession.

\section{References}

1. N. Hamdan, P. McKnight, K. McKnight, K. Arfstrom, A Review of Flipped Learning (2013), http://www.flippedlearning.org/cms/lib07/VA01923 112/Centricity/Domain/41/LitReview_FlippedLearn ing.pdf. Accessed 31 Mar 2020

2. J. Bishop, M. Verleger, The flipped classroom: A survey of the research, in ASEE National Conference Proceedings, Atlanta, 30(9) (2013)

3. R. Davies, D. Dean, N. Ball, Flipping the classroom and instructional technology integration in a collegelevel information systems spreadsheet course. Educational Technology Research and Development 61(4), 563-580 (2013)

4. I. Beres, M. Kis, Flipped Classroom Method Combined with Project Based Group Work, in Teaching and Learning in a Digital World, pp. 553562. doi:10.1007/978-3-319-73210-7_65

5. S. DeLozier, M. Rhodes, Flipped classrooms: a review of key ideas and recommendations for practice, Educational Psychology Review 29(1), 141-151 (2017). doi:10.1007/s10648-015-9356-9

6. O. Kuzminska, N. Morze, E. Smyrnova-Trybulska, Flipped learning model: Tools and experience of its implementation in higher education. New Educational Review 49(3), 189-200 (2017). doi:10.15804/tner.2017.49.3.15

7. J. McLaughlin, L. Griffin, D. Esserman, C. Davidson, D. Glatt, M. Roth, R. Mumper, Pharmacy student engagement, performance, and perception in a flipped satellite classroom. American Journal of Pharmaceutical Education 77(9), 196 (2013)

8. C. Little, The flipped classroom in fur ther education: literature review and case study. Research in PostCompulsory Education 20(3), 265-279 (2015). doi:10.1080/13596748.2015.1063260

9. C. Bruin, M. Albertyn, P. Machika, Changing the Departmental Learning Culture to Enable StudentCentred Learning in Large Classes. Mediterranean Journal of Social Sciences 5(8), 386-395 (2014)

10. K. Rajaram, Flipped Classrooms: Scaffolding Support System with Real-time Learning Interventions. Asian Journal of the Scholarship of Teaching and Learning 9(1), 30-58 (2019)

11. N. Nam, V. Giang, Flipped classroom model for improving computer skills of students majoring in pedagogy. Journal of vocational education and training 51(12), 44-49 (2017) 
12. O. Saad, M. Rana, Use of Cloud-based Learning Environment in Enhancing the Teaching and Learning Process for Software Engineering Courses, 246-252 (2014),

http://www.academia.edu/8279326/Use_of_Cloudba sed_Learning_Environment_in_Enhancing_the Tea ching_and_Learning_Process_for_Software_Engine ering_Courses. Accessed 31 Mar 2020

13. A. Salam, N. Sardar, Cloud Based Learning Environment. International journal of advanced information science and technology 4(6) (2015). doi:10.15693/ijaist/2015.v4i6.1-3.

14. M. Shyshkina, The Hybrid Cloud-based Service Model of Learning Resources Access and its Evaluation. CEUR Workshop Proceedings 1614, 241-256 (2016)

15. M. Shyshkina, The General Model of the Cloudbased Learning Environment of Educational Personnel Training, in Proceedings of the 20th International Conference on Interactive Collaborative Learning, ICL2017. Teaching and Learning in Digital World, 27-29 September, Budapest, Hungary, pp. 576-581

16. Y. Nosenko, M. Shyshkina, V. Oleksiuk, Collaboration between Research Institutions and University Sector Using Cloud-based Environment. CEUR Workshop Proceedings 1614, 656-671 (2016), http://ceur-ws.org/Vol-1614/paper_84.pdf. Accessed 1 Apr 2020

17. M. Shyshkina, M. Popel, The cloud-based learning environment of educational institutions: the current state and research prospects. Information Technologies and Learning Tools 37(5), 66-80 (2013)

18. O. Spirin, V. Oleksiuk, N. Balyk, S. Lytvynova, S. Sydorenko, The Blended Methodology of Learning Computer Networks: Cloud-based Approach. CEUR Workshop Proceedings 2393, 68$80 \quad$ (2019), http://ceur-ws.org/Vol2393/paper_231.pdf. Accessed 1 Apr 2020

19. V. Korolchuk, Cloud services for the implementation of collective projects in the process of preparation of future IT specialists: analysis and selection criteria. New pedagogical thought 100(4), 46-51 (2019)

20. N. Morze, O. Glazunova, Design of electronic learning courses for IT students considering the dominant learning style, in Information and Communication Technologies in Education, Research, and Industrial Applications, ICTERI 2014. ed. by V. Ermolayev, H. Mayr, M. Nikitchenko, A. Spivakovsky, G. Zholtkevych. Communications in Computer and Information Science, vol. 469 (Springer, Cham, 2014), pp. 261-273. doi:10.1007/978-3-319-13206-8_13 